\title{
AN ASSESSMENT OF SOME GROWTH AND YIELD INDICES OF SIX VARIETIES OF WATERMELON (CITRULUS LANATUS THUMB) IN ASABA AREA OF DELTA STATE, NIGERIA
}

EC Enujeke*

Department of Agronomy, Delta State University, Asaba Campus, Nigeria

Accepted: $09^{\text {th }}$ June 2014

\begin{abstract}
Field experiments were conducted in 2011 and 2012 cropping seasons in the Teaching and Research Farm of Delta State University, Asaba Campus, Nigeria to assess some growth and yield indices of six varieties of watermelon (Sugar baby, Charleston gray, Crimson sweet, Green gold, Jubilee, and Ice box) in Asaba area of Delta State, Nigeria. The experiments were carried out in a Randomized Complete Block Design (RCBD) with three replicates. Four parameters were assessed to achieve the objectives of the study-vine length, number of leaves/plant, number of branches /plant, and weight of fruits at 75 days after sowing. The results of the two-year evaluation indicated that Sugar baby variety was superior at 4,6 , and 8 weeks in the parameters tested with mean vine length of 63.4 $\mathrm{cm}, 133.1 \mathrm{~cm}$, and $181.1 \mathrm{~cm}$, respectively; mean number of leaves/plant of 30.5, 33.5 and 40.4 respectively; mean number of branches/plant of 5.0, 6.0, and 7.0, respectively; and mean weight of fruits of $1315.43 \mathrm{tha}^{-1}$ at 75 days after sowing in 2011 and 2012. Based on the findings of this study, it was recommended that farmers in the study area grow Sugar baby variety for increased growth and yield of watermelon.
\end{abstract}

Key words: Asaba, Growth and yield indices, Nigeria, Varieties of watermelon

\section{INTRODUCTION}

Watermelon (Citrullus lanatus Thumb) is a member of the cucurbitaceae family. It is believed to have originated from the Kalahari and Sahara deserts in Africa (Jarret et al. 1996). In Nigeria, its cultivation which was originally confined to the drier savannah regions of the North, is now gradually gaining ground in the southern parts of the country. It is a crop with huge economic importance to man. The fresh fruit is relished by many people across the world because it is known not only to be low in calories but highly nutritious, sweet and thirstquenching (Mangila et al. 2007). It is commonly used to make a variety of salads, most notably fruit salad. It is a popular cash crop grown by farmers during summer due to its high returns in investment, especially those residing near the urban areas. Watermelon contains Vitamin $\mathrm{C}$ and $\mathrm{A}$ in form of the disease fighting beta-carotene. Potassium is also available in it, which is believed to help in the control of blood pressure and possibly prevent stroke (IITA, 2013).
Water melon production in Nigeria is not enough for local demand. Declining soil fertility is one reason for low production. Identification of high yielding varieties best adapted or most suitable to each agro-ecological zone is a must to increase melon production. Iken and Anusa (2004) reported that because of the differences in yield potential of different ecological zones, testing of new crop varieties across the country became an established practice in plant breeding. The report further argued that though high yielding crop varieties can only express their full genetic resources, the yield advantages and special traits of hybrids appear to be sufficiently large enough to attract the attention of farmers. The report also recommended the right choice of site, timely and appropriate establishment, nutrition; disease and pest control, proper harvesting procedure and produce disposal and/or storage. Varietal differences affect or determine the growth and yield of crops. Majanbu et al. (1996) and Sajjan et al. (2002) reported that growth characters of crops such as plant height, vine length, leaf area, number of leaves or branches, 
and fruit production were influenced by genetic factors of the different varieties. Ibrahim et al. (2000) reported that the differences in growth indices of crops are normally attributed to their genetic constitution. Akinfoesoye et al. (1997); Odeleye and Odeleye (2001) indicated that growth characters, yield and its component differed among crop varieties and therefore suggested that breeders must select most promising combiners in their breeding programmes. Ray and Sinclair (1997) attributed differences between the growth characters of crop genotypes to photosynthetic activity of leaves i.e. internal factors and/or to the differences in high distribution on leaf surface of the crop canopy, leaf arrangement, differences in chlorophyll content, activity of photosynthetic enzymes and differences in stomatal conductance values. Costa and Campos (1990); Gardner et al. (1990) and Zaki et al. (1999) attributed yield differences in crop cultivars to stomata conductance value and to differences between genotypes in partitioning of photosynthetic materials towards economic yield. Clark et al. (1997) reported that the genotypes differences in yield and its components may be due to variations in genetic structure, mineral concentration and potentials to transport photosynthetic materials within plants.

At present, no variety of watermelon has been identified as best adapted or most suitable for Asaba area of Delta State, Nigeria. The objective of this study, therefore, was to assess the growth and yield indices of six different varieties of watermelon with a view to identifying the best adapted or most suitable variety for the study area.

\section{MATERIALS AND METHODS}

Field experiments were carried out at the Research and Teaching Farms of Anwai Campus of the Delta State University. The experimental site is located within latitude $06^{\circ} 14^{\prime} \mathrm{N}$ and longitude $06^{\circ} 49^{\prime} \mathrm{E}$ of the equator. The experiment was conducted during the 2011/2012 cropping seasons in a typical humid environment that is characterized by a bimodal rainfall pattern with peaks in July and September and an interrupted dry spell in August otherwise called (Harmattan). The annual mean rainfall is about $1,650 \mathrm{~mm}$, the mean annual temperature is $37.3^{\circ} \mathrm{C}$ and a mean relative humidity of $73.2 \%$ (NIMET, 2011). By nature of its geomorphological settings, the study area falls within the classification of Ancient metamorphic crystalline basement complex formation which are more acid than base (Egbuchua, 2007). They are essentially gneisses and pegmatites that gave rise to coarse-textured soils that are deficient in dark ferromagnessium minerals (Egbuchua, 2007).The topography is undulating with pockets of hills and land use is typically based on rain - fed agriculture with root, tuber, spices, pulses and vegetables prominently cultivated. The vegetation is of rainforest origin but has been drastically reduced to derived savanna due to continuous use of the land. The land measured $388.85 \mathrm{~m}^{2}(38.5 \mathrm{~m} \mathrm{x}$ $10.1 \mathrm{~m})$. It was ploughed and harrowed using a tractor, and marked out according to the experimental layout. Eighteen plots of $6.0 \mathrm{~m} \times 2.7 \mathrm{~m}$ each were made and composite samples collected from the plots at $0-15 \mathrm{~cm}$ depth in order to assess the initial physio-chemical properties of the soil. The composite soil samples collected from the individual plots were air-dried in a room temperature of $27^{\circ} \mathrm{C}$ for three days, crushed and sieved using $2 \mathrm{~mm}$ aperture. The parameters evaluated include the particle size distribution by hydrometer method (Gee and Bauder, 1986). The $\mathrm{pH}$ was determined using PyeUnican model MK2 $\mathrm{pH}$ meter in a 1:2:5 soil/water suspension ratio. Organic carbon was determined by Walkley-Black wet oxidation method (Nelson and Sommers, 1982). Total nitrogen was determined by micro-Kjeldahl distillation technique as described by Breminer and Mulvaney (1982). Available phosphorus was determined by Bray No. 1 method (IITA, 1979). Exchangeable potassium was determined by flame photometer, while cation exchange capacity (CEC) was determined by Amnonium acetate saturation method (Roades, 1982).

The experiment was carried out in a Randomized Complete Block Design (RCBD) with three replicates. Six varieties of watermelon 
were sown- Sugar baby, Charleston gray, Crimson sweet, Green gold, Jubilee, and Ice box. Poultry manure was uniformly incorporated at the rate of $30 \mathrm{t} \mathrm{ha}^{-1}$ into the soil 2 weeks before planting. The six watermelon varieties were collected from Agro - Allied Company, Ibadan, and sown on the plots at 2 seeds per stand at a depth of $2.5 \mathrm{~cm}$, using a spacing of $90 \mathrm{~cm} \times 75 \mathrm{~cm}$, with $1 \mathrm{~m}$ Alley pathways. Regular weeding was done around the base, along and ahead of the vines using hoe. Fourteen middle stands were used as sample population. Data collected were vine length, number of leaves/plant, number of branches/plant, and fruit weight at maturity. Vine length was measured with tape from the base to the growing tip of the plant. Number of leaves/plant and number of branches/plant were determined by direct counting. Fruit weight was measured using a weighing scale, after harvesting at 75 days from planting. Data collected was subjected to analysis of variance (ANOVA) and means were separated using Duncan Multiple Range Test (DMRT) according to Wahua (1999).

\section{RESULTS AND DISCUSSION}

\section{Initial soil properties}

The data on the initial physico-chemical properties of the soils used for the study is presented in Table 1. The particle size fracture showed that the soils were sandy loam in texture and low in fertility as reflected by the low content of organic matter $\left(15.5 \mathrm{~g} \mathrm{~kg}^{-1}\right)$, and total nitrogen $\left(0.87 \mathrm{~g} \mathrm{~kg}^{-1}\right)$. Soil $\mathrm{pH}$ was strongly acid with a mean value of 5.3. The available phosphorus $(\mathrm{P})$ and water soluble, potassium $(\mathrm{K})$ with mean values of $5.35 \mathrm{mg}$ $\mathrm{kg}^{-1}$ and $0.17 \mathrm{cmol} \mathrm{kg}^{-1}$ were seemingly low based on the ratings of FMANR (1996) for the ecological zone. The low fertility status of the soils is a true reflection of most ultisols of humid environment that are strongly weathered of low activity clay mineralogy and high acidity due to intense precipitation with its associated erosion and leaching in the environment.

Table 1: Initial phyisco-chemical properties of the soils used for the study

\begin{tabular}{ll}
\hline $\begin{array}{l}\text { Parameters } \\
\text { Measured }\end{array}$ & $\begin{array}{c}\text { Values obtained } \\
(\%)\end{array}$ \\
\hline Sand & 85.0 \\
Silt & 9.6 \\
Clay & 4.4 \\
Textural class & Sandyloam \\
pH $\left(\mathrm{H}_{2} \mathrm{O}\right)$ & 5.3 \\
Organic matter g kg-1 & 15.5 \\
Total Nitrogen $\left(\mathrm{g} \mathrm{kg}^{-1}\right)$ & 0.87 \\
Available $\mathrm{P}\left(\mathrm{mg} \mathrm{kg}^{-1}\right)$ & 5.35 \\
Exchangeable K $\left(\mathrm{Cmol} \mathrm{kg}^{-1}\right)$ & 0.17 \\
CEC $\left.(\mathrm{Cmol} \mathrm{kg})^{-1}\right)$ & 10.13 \\
\hline
\end{tabular}

Vine length $(\mathrm{cm})$ of six watermelon varieties at different weeks after sowing in 2011 and 2012

The vine length of six watermelon varieties from 4-8 weeks after sowing in 2011 and 2012 is shown in Table 2. Vine length of watermelon gradually increased from 4-8 weeks after sowing. There were significant differences in vine length of the varieties investigated. At 4 weeks after sowing in both years of evaluation, Sugar baby variety had the highest vine length with a mean value of 63.4 $\mathrm{cm}$, while Ice box variety had the lowest vine length with a mean value of $43.2 \mathrm{~cm}$. During the $6^{\text {th }}$ week of both years, Sugar baby variety also had the highest vine length with a mean value of $133.1 \mathrm{~cm}$, while Ice box variety also had the lowest vine length with mean value of $76.2 \mathrm{~cm}$. The trend did not change during the $8^{\text {th }}$ week. Sugar baby variety was also superior in vine length with mean value of $181.1 \mathrm{~cm}$, while Ice box variety which had a mean value of $92.3 \mathrm{~cm}$ was lowest. The order of superiority in vine length of watermelon based on varieties investigated was Sugar baby $>$ Charleston gray $>$ Crimson sweet $>$ Green gold $>\mathrm{Ju}-$ bilee $>$ Ice box.

The higher mean value of vine length of Sugar baby variety over other watermelon varieties tested may be attributed to differences in its genetic constitution with respect to 
Table 2: Vine length (cm) of six watermelon varieties at different weeks after sowing in 2011 and 2012

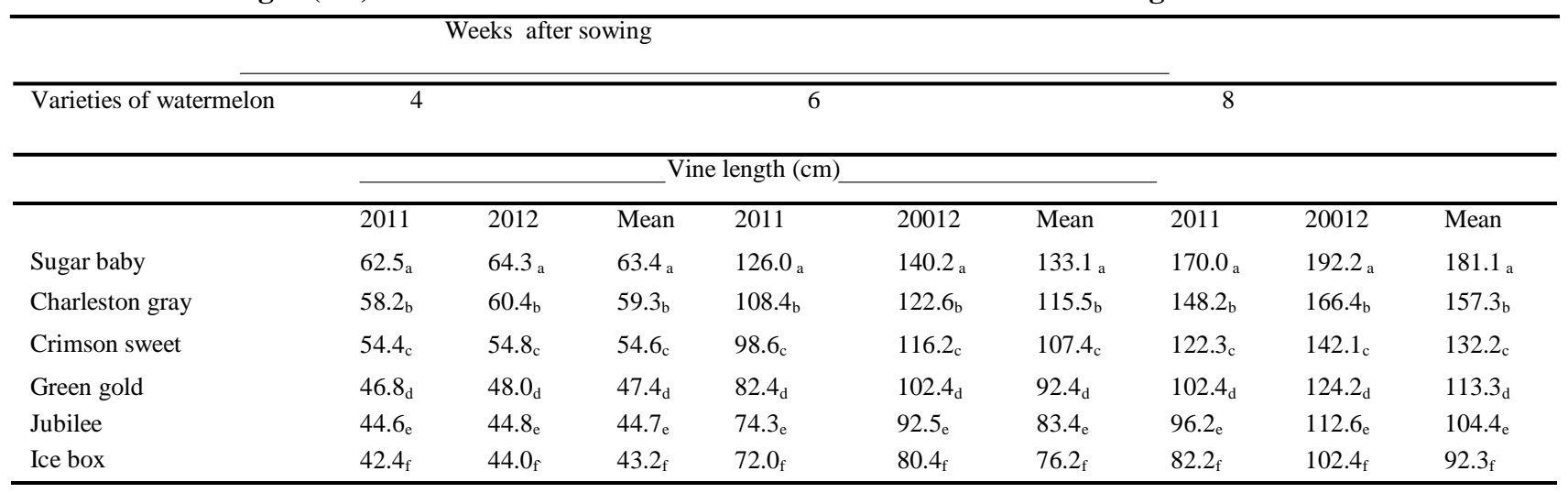

Means with the same letter(s) under the same column are not significantly different $(\mathrm{P} \leq 0.05)$ using Duncan Multiple Range test (DMRT)

higher growth rate of the vine, and to suitability of Asaba agro-ecological conditions for the variety. This is similar to the findings Majanbu et al. (1996); Ibrahim et al. (2000); and Sajjan et al. (2002), who reported that genetic constitution of crop varieties influence their growth characters. It is also in harmony with the findings of Iken and Anusa (2004) who attributed the growth and yield differences among crop varieties to right choice of suitable agro-ecological zone.

\section{Number of leaves/plant of six watermelon varieties at different weeks after sowing in 2011 and 2012}

The number of leaves of six varieties of watermelon at different weeks after sowing in 2011 and 2012 cropping seasons is shown in Table 3. Number of leaves of watermelon gradually increased from 4-8 weeks after sowing. There were significant differences also in the number of leaves of the watermelon varieties tested. At 4 weeks after sowing in 2011 and 2012, Sugar baby variety had the highest number of leaves/plant with a mean value of 30.5 , while Ice box variety with mean value of 17.6 had the lowest number of leaves/plant. During the $6^{\text {th }}$ week of both years of evaluation, Sugar baby variety also had the highest number of leaves/plant with a mean value of 33.5, while Ice box variety which had a mean value of 19.2 had the lowest number of leaves/plant. Similar trend was observed during the $8^{\text {th }}$ week where Sugar baby variety proved superior in number of leaves/plant with a mean value of 40.4 , while Ice box variety which had a mean value of 23.2 had the lowest number of leaves/plant. Based on variety, the order of superiority in number of

Table 3.Number of leaves/plant of six watermelon varieties at different weeks after sowing in 2011 and 2012.

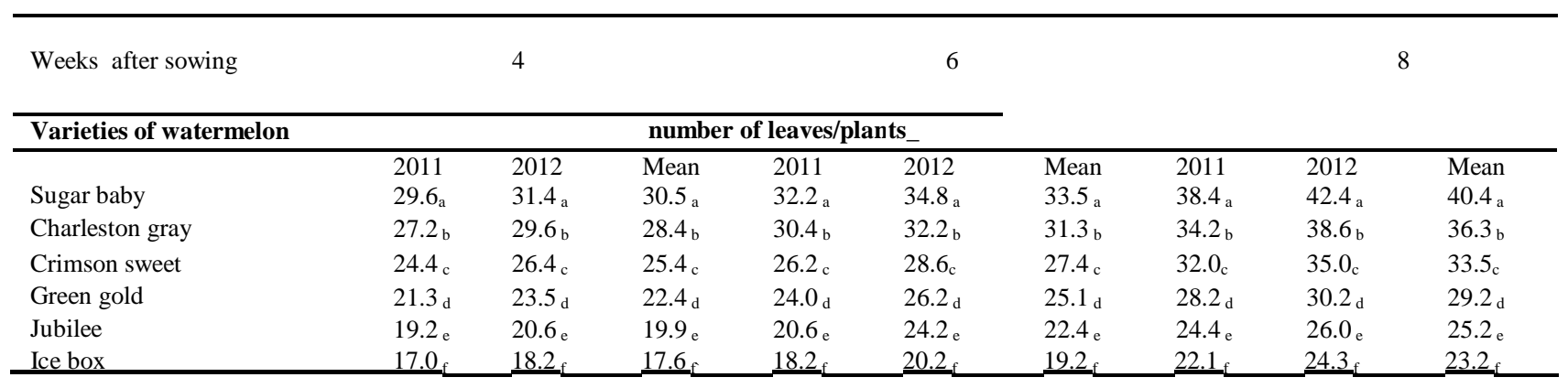

Means with the same letter(s) under the same column are not significantly different $(\mathrm{P} \leq 0.05)$ using Duncan Multiple Range test (DMRT) 
leaves/plant of watermelon was Sugar baby > Charleston gray > Crimson sweet > Green gold $>$ Jubilee $>$ Ice box.

The number of leaves/plant of Sugar baby variety was higher than that of other varieties investigated possibly because Sugar baby had higher photosynthetic activities, better distribution of leaf surface, superior leaf arrangement and chlorophyll content, and more active photosynthetic enzymes. This is in harmony with the findings of Ray and Sinclair (1997) and Enujeke (2013) who attributed the differences between the growth characters of crop varieties to photosynthetic activities of leaves, differences in distribution of leaf surface and crop canopy, leaf arrangement, differences in chlorophyll content and activity of photosynthetic enzymes.

\section{Number of branches/plant of six water- melon varieties at different weeks after sowing in 2011 and 2012}

The number of branches/plant of watermelon from 4-8 weeks after sowing in 2011 and 2012 is shown in Table 4. There were significant differences in the number of branches/ ety which had a mean value of 2.0 had the lowest number of branches/plant. During the $6^{\text {th }}$ week of both years, Sugar baby variety also had the highest number of branches/plant with a mean value of 6.0 , while Ice box variety with a mean value of 3.0 had the lowest number of branches/plant. The trend did not change during the $8^{\text {th }}$ week. Sugar baby variety also had the highest number of branches/ plant with a mean value of 7.0, while Ice box variety which had a mean value of 4.0 had the lowest number of branches/plant. Based on variety, the order of superiority in number of branches/plant of watermelon was Sugar baby $>$ Charleston gray > Crimson sweet > Green gold $>$ Jubilee $>$ Ice box.

Higher number of branches/plant was observed in Sugar baby variety possibly because that particular variety combined its good genetic make-up to exploit the newly found favourable agro-ecological conditions of the study area for rapid growth and branching. This is in harmony with the reports of Akinfoesoye et al. (1997) and Ray and Sinclair (1997) who attributed the growth characters of crop species not only to genetic constitution of the crop but also to the suitable agro-

Table 4.Number of branches/plant of six watermelon varieties at different weeks after sowing in 2011 and 2012

\begin{tabular}{|c|c|c|c|c|c|c|c|c|c|}
\hline & 4 & & & 6 & & & 8 & & \\
\hline & \multicolumn{6}{|c|}{ number of branches/plants } & \multirow[b]{2}{*}{2011} & \multirow[b]{2}{*}{2012} & \multirow[b]{2}{*}{ Mean } \\
\hline & 2011 & 2012 & Mean & 2011 & 2012 & Mean & & & \\
\hline \multicolumn{10}{|c|}{ Varieties of watermelon } \\
\hline Sugar baby & $5.0_{\mathrm{a}}$ & $5.0_{\mathrm{a}}$ & $5.0_{\mathrm{a}}$ & $6.0_{\mathrm{a}}$ & $6.0_{\mathrm{a}}$ & $6.0_{\mathrm{a}}$ & $7.0_{\mathrm{a}}$ & $7.0_{\mathrm{a}}$ & $7.0_{\mathrm{a}}$ \\
\hline Charleston gray & $3.0_{\mathrm{b}}$ & $3.0_{\mathrm{b}}$ & $3.0_{\mathrm{b}}$ & $4.0_{\mathrm{b}}$ & $4.0_{\mathrm{b}}$ & $4.0_{\mathrm{b}}$ & $5.0_{\mathrm{b}}$ & $5.0_{\mathrm{b}}$ & $5.0_{\mathrm{b}}$ \\
\hline Crimson sweet & $3.0_{\mathrm{b}}$ & $3.0_{\mathrm{b}}$ & $3.0_{\mathrm{b}}$ & $4.0_{\mathrm{b}}$ & $4.0_{\mathrm{b}}$ & $4.0_{\mathrm{b}}$ & $5.0_{\mathrm{b}}$ & $5.0_{\mathrm{b}}$ & $5.0_{\mathrm{b}}$ \\
\hline Green gold & $2.6_{\mathrm{b}}$ & $2.4_{\mathrm{b}}$ & $2.5 \mathrm{~b}$ & $3.5 \mathrm{~b}$ & $3.5 \mathrm{~b}$ & $3.5 \mathrm{~b}$ & $4.4_{b}$ & $4.6_{b}$ & $4.5 \mathrm{~b}$ \\
\hline Jubilee & $2.4_{b}$ & $2.4_{b}$ & $2.4_{b}$ & $3.4_{b}$ & $3.2_{\mathrm{b}}$ & $3.3_{\mathrm{b}}$ & $4.2_{\mathrm{b}}$ & $4.2_{\mathrm{b}}$ & $4.2 \mathrm{~b}$ \\
\hline Ice box & $1.8_{\mathrm{c}}$ & $2.2 \mathrm{~b}$ & $2.0_{\mathrm{bc}}$ & $2.8_{\mathrm{c}}$ & $3.2_{\mathrm{b}}$ & $3.0_{\mathrm{bc}}$ & $3.8_{\mathrm{c}}$ & $4.2 \mathrm{~b}$ & $4.0_{\mathrm{bc}}$ \\
\hline
\end{tabular}

Means with the same letter(s) under the same column are not significantly different $(\mathrm{P} \leq 0.05)$ using Duncan Multiple Range test (DMRT).

plant of the varieties sown. At 4 weeks of both years of evaluation, Sugar baby variety had the highest number of branches/plant with a mean value of 5.0, while Ice box vari- ecological zone where they can express their full genetic resources for growth and yield enhancement. 
Weight of fruits $\left(\mathrm{t} \mathrm{ha}^{-1}\right)$ of watermelon varieties at 75 days after sowing in 2011 and 2012

The weight of fruits of watermelon at 75 days after sowing in 2011 and 2012 cropping seasons is shown in Table 5. There were significant differences in weight of fruits of the varieties investigated. In both years of evaluation, Sugar baby variety had the highest weight of fruits with a mean value of 1315.43 tha $^{-1}$ while Ice box variety had the lowest weight of fruits with a mean value of $756.30 \mathrm{t}$ $\mathrm{ha}^{-1}$. Based on variety, the order of superiority in weight of fruits of watermelon was Sugar baby > Charleston gray > Crimson sweet > Green gold $>$ Jubilee $>$ Ice box.

Table 5.Weight of fruits $\left(\right.$ tha $\left.^{-1}\right)$ of watermelon varieties at 75 days after sowing in 2011 and 2012

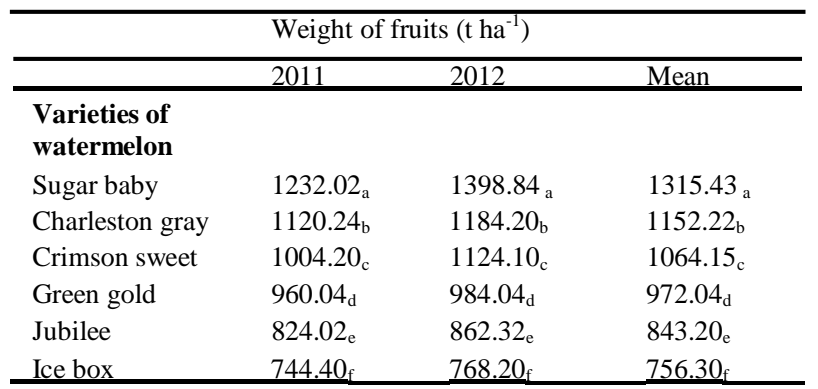

Means with the same letter(s) under the same column are not significantly different $(\mathrm{P} \leq 0.05)$ using Duncan Multiple Range test (DMRT)

The higher weight of fruits observed in Sugar baby variety over other varieties investigated may be attributed to possibility of possession of higher stomatal conductance, better partitioning of photosynthetic materials towards economic yield, better genetic structure and higher potential to transport photosynthetic material within plants. This is in harmony with the reports of Costa and Campos (1990); Gardner et al., (1990) and Zaki et al. (1999) which attributed the yield differences in crop cultivars to stomatal conductance value and to differences in partitioning of photosynthetic materials towards economic yield. It is also in consonance with the findings of Clark et al.
(1997) who attributed the differences in yield and its components between crop genotypes to variations in genetic structure, mineral concentration and potentials to transport photosynthetic materials within plants.

\section{CONCLUSION}

This study was carried out to assess some growth and yield indices of six watermelon varieties in Asaba Area of Delta State, Nigeria. The results obtained showed that Sugar baby variety was superior in the parameters investigated. Based on the findings of the study, it was recommended that farmers in the study area plant Sugar baby variety of watermelon for enhanced growth and yield.

\section{REFERENCES}

Akinfosoye JA, Olafolaji AO, Tairu FM and Adenowola RA 1997 Effect of different phosphorus levels on the yield of four varieties of rained tomato (Lycopersicom esculentum). Proceedings of the $15^{\text {th }}$ HORTSON Conference (1): 65-66.

Bremmer JM and CS Mulvaney 1982 Total nitrogen In: Page AL Miller, RH and Keeney DR (eds.) Methods of soil analysis. Part 2. Agron 9, Madison. W.I. pp. 149-157.

Clark RB, Zeto SK, Baligar VC and Ritchey KD 1997 Growth traits and mineral concentrations of maize hybrids grown on unlimed and limed acid soil. Journal of Plant Nutrition 20(12): 1773-1795.

Costa JG and Campos DAJS 1990 Maize cultivars recommended for the state of Acre. Counica de Tecnicounidaded' Exeecuo de Numbito Estand. No. 56, pp4 (c.f. Field Crop Abstracts 1991, volume 44, No.12).

Enujeke EC 2013 Effects of variety and spacing on growth characters of hybrid maize. Asian Journal of Agriculture and Rural Development. 3(5): 296-310. 
FMANR-Federal Ministry of Agricultural and Natural Resources (1996) Soil fertility investigation, Fertility ratings. Produced by the Federal Ministry of Agriculture, Lagos, Nigeria.

Gardner FP, Alle V and McCloud DE 1990 Yield characteristics of ancient roses of maize compared to modern hybrid. Agronomy Journal. 82(5): 864-868.

Gee GW and Bauder JW 1986 Particle size analysis p. 404-407. In: Klute A (ed) Methods of soil analysis. Part 1 ( $2^{\text {nd }}$ ed.) Agron. Monogr. 9. ASA and SSSA. Madison W.I. USA.

Ibrahim K Amans A and Abubakar IU 2000 Growth indices and yield of tomato (Lycopesicon esculentum karest) varieties as influenced by crop spacing at samaru. Proceedings of the $18^{\text {th }}$ HORTSON Conference Proceedings (1): 4047.

IITA International institute for Tropical Agriculture (1979) Laboratory manual for soil and plant analysis. Manual series 7, IITA, Ibadan, Nigeria.

IITA 2013 Growing watermelon commercially in Nigeria- an illustrated guide. International Institute of Tropical Agriculture (IITA), pp. 1-16.

Iken JE and Anusa A 2004 Maize research and production in Nigeria. African Journal of Biotechnology 3(6): 302-307.

Jarret B, Bill R, Tom W and Garry A 1996.Cucurbits Germplasm Report, Watermelon National Germplasm System, Agricultural Service, U.S.D.A. pp: 2966.

Majanbu IS, Ogunlella VB and Ahmed MK 1996 Responses of two okro (Abelmoschus esculentus (L) Moench) varieties to fertilizer growth and nutrient concentration as influenced by nitrogen and phosphorus applications. Fertilizer Research 8(3): 297-306.

Mangila E, Tabiliran FP, Naguit MRA and Malate R 2007 Effects of organic fertilizer on the yield of watermelon. threshold 2. January-December, 2007, pp 27-35.

Nelson DW and IE Sommers 1982 Organic Carbon. In: Page Miller AL, RH and Keeney DR (eds.) Methods of Soil analysis. Part 2 Agron, Monogr. 9 ASA and SSSA, Madison, W.I. USA.

NIMET-Nigerian Meteorological Agency (2011) Climate information Bulletin (2011-2012) Asaba, Delta State, Nigeria.

Odeleye FO and Odeyeye MO 2001 Evaluation of morphological and agronomic characteristics of two exotic and two adapted varieties of tomato (Lycopersicom esculentum) in South West Nigeria. Proceedings of the $19^{\text {th }}$ Annual Conference of HORTSON. (1):140-145.

Ray JD and Sinclair TR 1997 Stomatal closure of maize hybrid in response to drying soil. Crop Science 37(30): 803-807.

Roades JD 1982 Cation Exchange Capacity. In: Page, Miller AL, RH and Keeney, DR (eds.) Methods of soil analysis. Part 2 Agron. Monogr. ASA, SSSA, Madison, W.I. USA.

Sajjan AS, Shekhargounda M, and Badanur 2002 Influence of data of sowing, spacing and levels of nitrogen on yield attributes and seed yield of Okro. Ikamataka Journal of Agricultural Science 15 (2): 267-274.

Wahua TAT 1999 Applied statistics for scientific studies. Afrika-Link Books, Nigeria, pp. $250-287$.

Wikepedia encyclopedia 2010 Growth and yield performance of watermelon.www.wikipedia.com.l production guide of watermelon.da.gov.ph2010 http:// www.da.gov.ph/2010 .

Zaki NM, El-Gazar MM, El-Din KMG and Ahmed MA 1999 Partition and migration of photosynthates in some maize hybrids. Egypt Journal of Applied Sciences 14(6): 117 - 139. 